\title{
ANALISIS MINAT BELAJAR SISWA SD PANGKALAN MENCARI VOLUME BANGUN RUANG BERBANTUAN PERANGKAT LUNAK GEOGEBRA
}

\author{
Bunga Permaganti $^{1}$, Sintia Rahayu ${ }^{2}$, Wahyu Setiawan ${ }^{3}$ \\ 1,2,3 IKIP Siliwangi, Jl. Terusan Jenderal Sudirman, Cimahi \\ bungapermaganti07@gmail.com
}

\begin{abstract}
This study aims to analyze student interest in learning through the GeoGebra program. The method used in this study is a descriptive qualitative method with a population of all elementary school students in Pangkalan Bandung. The sample used in this study was 29 fifth grade elementary school students in Pangkalan in the matter of building volume. The instrument used was the Student Interest Scale with many 20 statement statements that had positive and negative responses about learning using the GeoGebra program. The scale of students 'interest in learning is used to look for responses from respondents on elementary / MI students' interest in learning on the GeoGebra program material. The results of this study indicate a positive response to the learning of the volume of the building using the GeoGebra program with the average response given indicates a strong category with the percentage of results obtained is $66,69 \%$. The average is obtained from the data of each indicator of student interest in learning.
\end{abstract}

Keywords: Student interest in learning, volume of wake space, geogebra software

\begin{abstract}
Abstrak
Penelitian ini bertujuan untuk menganalisis minat belajar siswa melalui program GeoGebra. Metode yang digunakan pada penelitian ini adalah metode deskriptif kualitatif dengan populasi seluruh siswa SD Pangkalan Kota Bandung. Sample yang digunakan pada penelitian ini adalah siswa kelas V SD Pangkalan sebanyak 29 orang siswa pada materi volume bangun ruang. Instrument yang digunakan yaitu Skala Minat Siswa dengan banyak pernyataan 20 pernyataan yang mempunyai tanggapan yang positif dan negative tentang pembelajaran menggunakan program GeoGebra. Skala minat belajar siswa digunakan untuk mencari tanggapan dari para responden terhadap minat belajar siswa SD/MI pada materi program GeoGebra. Hasil dari penelitian ini menunjukkan tanggapan yang positif terhadap pembelajaran volume bangun ruang dengan menggunakan program GeoGebra dengan rata-rata respon yang diberikan menunjukkan kategori yang kuat dengan hasil presentase yang diperoleh adalah $66,69 \%$. Rata-rata tersebut didapat dari data setiap indicator minat belajar siswa.
\end{abstract}

Kata Kunci: Minat Belajar Siswa, Volume Bangun Ruang, Perangkat Lunak Geogebra

Pendidikan matematika merupakan pelajaran yang berperanan penting dalam dunia Pendidikan. Hampir setiap mata pelajarannya membutuhkan matematika bahkan dalam segala aspek kehidupanpun, matematika selalu dipergunakan dalam kehidupan sehari-hari. Maka dari itu, matematika menjadi suatu keharusan untuk dipelajari agar masalah yang terjadi dalam kehidupan sehari-hari dapat dipecahkan meskipun kebanyakan orang menganggap matematika itu adalah sebuah bidang studi yang sulit untuk dipelajari dan kebanyakan orang cenderung merasa malas bahkan merasa tak tertarik mempelajari matematika. Bahkan siswa yang sedang menjalalani pendidikanpun lebih cenderung kebanyakan mempelajari matematika hanya karna keterpaksaan sebagai prasyarat untuk menempuh pendidikan tersebut.

Ada beberapa hal yang menyebabkan siswa sulit bahkan cenderung malas untuk belajar matematika. Ada 3 hal yang yang menjadi penyebab siswa mengalami kesulitan dalam mempelajari matematika menurut (Jamal, 2014) yaitu: persepsi (perhitungan dalam pelajaran metamatika), 
intervensi dan ekstrafolasi dalam pelaksanaan proses belajar mengajar akan menjadi penentu sampai sejauh mana keberhasilan yang harus dicapai siswa pada mata pelajaran matematika

Pemaparan konsep pada pembelajaran matematika menjadikan pembelajaran matematika tersebut semakin membosankan untuk dipelajari terlebih dengan pembelajarannya yang sulit membuat siswa menjadi semakin tak tertarik mempelajari matematika. Pemaparan konsep yang diberikan oleh guru pula kebanyakan dalam bentuk abstrak sehingga menyebabkan siswa berpikir bahwa konsepkonsep yang diajarkan tidak terdapat dalam kehidupan sehari-hari. Padahal pada kenyataannya, matematika banyak dijumpai dan banyak kita gunakan untuk pemecahan suatu permasalahan dalam kehidupan sehari-hari.

Minat belajar dalam belajar matematika menjadi salah satu bagian penting dalam proses belajar matematika untuk melahirkan perhatian siswa dalam belajar. Seperti yang dikatakan oleh Asmani dalam (Sirait, 2016), bahwa minat adalah perasaan suka dan ketertarikan yang lebih pada sesuatu hal atau suatu aktifitas tanpa ada yang menyuruh. Hal ini serupa dengan yang dikatakan Slameto (2010: 57), yang menyatakan bahwa bahwa: "Interest is persisting tendency to pay attention to and enjoy same activities and or content" ("Minat adalah kecenderungan yang tetap untuk memperhatikan dan mengenang beberapa kegiatan"). Kegiatan-kegiatan ini meliputi kegiatan yang diminati siswa dan akan diperhatikan terus menerus yang disertai rasa senang.

Media salah satu dari bagian penting pada pembelajaran terlebih pada pembelajaran matematika. Media penting dalam matematika karna objek dalam matematika itu bersifat abstrak sehingga membutuhkan suatu alat bantu peraga pembelajaran. Hal ini sama halnya dengan paparan dari Kementerian Pendidikan dan Kebudayaan RI, 2014 dalam (Ramdhani, 2017), bahwa media mempunyai peranan penting bagi pembelajaran matematika karena 1) objek pada matematika memiliki sifat yang abstrak sehingga membutuhkan alat peraga; 2) Sifat materi pada matematika yang tidak mudah dipahami; 3) Hirarki dalam matematika itu ketat dan kaku; 4) Aplikasi pada matematika pun kurang nyata; 5) Belajar matematika perlu kefokusan yang cukup; 6) Citra pada pembelajaran matematika kurang baik; 7) Kemampuan kognitif siswa yang masih bersifat konkret; 8) Motivasi siswa dalam belajar yang masih rendah.

Kurangnya minat belajar siswa yang juga menjadi factor penyebab dari sulitnya mempelajari pelajaran matematika. Menurut Rojabiyah, \& Setiawan, 2019 dalam (Rahmawati, Bungsu, Islamiah, \& Setiawan, 2015), bahwa minat belajar merupakan suatu kegiatan pembelajaran yang dilakukan oleh seseorang dalam proses kegiatan pembelajaran secara konsisten datang dari diri sendiri dengan perasaan senang dalam dirinya dan tanpa adanya paksaan dari orang lain. Minat belajar siswa sangat berpengaruh kepada hasil belajar siswa.

Minat belajar siswa dapat dikembangkan dengan berbagai cara, misalnya dilihat dari bagaimana cara penyampaian pembelajaran guru kepada siswa. Proses penyampaian pembelajaran guru terhadap siswa ialah salah satu yang menjadi faktor penyebab rendahnya minat belajar yang terjadi pada siswa 
karna jika proses penyampaian pembelajaran terasa monoton itu akan membuat minat belajar siswa menjadi menurun.

Media pembelajaran menjadi salah satu cara untuk memudahkan dan menarik minat siswa untuk dapat menangkap pemahaman pembelajaran yang sedang dipelajari. Media pembelajaran sebagai suatu alat untuk membantu proses belajar mengajar. Media pembelajaran yaitu segala sesuatu yang dapat dipergunakan untuk dijadikan rangsangan pemikiran, perasaan, kemampuan serta keterampilan, serta perangsang perhatian pelajar sehingga dapat mendorong ketercapaian proses belajar mengajar secara optimal. Media pembelajaran yang simple pada umumnya memakai media computer. Menurut Hartono dalam (Kartika, 2014), bahwa computer yang merupakan suatu system yang didalamnya terdiri atas perangkat lunak (software) dan perangkat keras (hardware) menjadi salah satu media yang cocok untuk digunakan dalam penunjang proses belajar-mengajar.

Menurut Leshin, Pollock \& Reigeluth (1992) dalam (Ramdhani, 2017), mengklasifikasikan media pembelajaran dalam 5 kelompok, yaitu: 1) Media pembelajaran yang berbasis manusia; 2) Berbasis cetak; 3) Berbasis visual 4) Berbasis audio-visual; dan 5) Berbasis komputer. Diantara kelima kelompok media pembelajaran tersebut, media pembelajaran berbasis komputer mempunyai beberapa kelebihan diantaranya dapat meningkatkan, mengembangkan dan memperluas pembelajaran yang dapat memungkinkan siswa untuk dapat merancang eksplorasi sendiri dan menyusun pengetahuan atau ideidenya sendiri. Penggunaan media teknologi ini seperti media pembelajaran yang interaktif pada pembelajaran matematika yang akan membuat pembelajaran matematika dengan objek-objek yang bersifat abstrak menjadi lebih terlihat nyata karena ditampilkan dalam bentuk visualisasi. Tampilan visualisasi bagi para siswa ini akan lebih memudahkan, menyenangkan serta membuat siswa lebih tertarik dalam mempelajari pembelajaran matematika (Ramdhani, 2016).

Terlebih tuntutan era globalisasi serta perkembangan IPTEK sekarang ini, mengharuskan untuk para generasi muda menguasai ilmu teknologi. Perkembangan ilmu teknologi akan membawa perubahan dan sangat berpengaruh pada dunia pendidikan. Ilmu teknologi yang lazim digunakan pada dunia pendidikan yaitu komputer dengan berbagai perangkatnya. Salah satu perangkat lunak pada komputer yang dapat dipakai dalam pembelajaran matematika yaitu perangkat lunak GeoGebra. GeoGebra ini merupakan suatu perangkat lunak Pendidikan matematika gratis yang di ditawarkan oleh Hohenwarter dan Judith Preiner. Perangkat lunak ini memiliki berbagai macam fasilitas. GeoGebra ini sangat cocok dijadikan sebagai media pembelajaran matematika. Perangkat lunak GeoGebra ini dapat mendemonstrasikan ataupun menvisualisasikan berbagai macam konsep-konsep dalam pembelajaran matematika. Perangkat lunak GeoGebra sebagai salah satu media pembelajaran sangat bermanfaat bagi guru sebagai salah satu alat bantu dalam menyampaikan proses belajar mengajar yang tidak menjenuhkan dan cenderung menarik perhatian siswa. Sejalan dengan Khairani, 2016; Ahern, 2016 dalam (Masykur, Nofrizal, \& Syazali, 2017), yang menyatakan bahwa media pembelajaran merupakan faktor pendukung keberhasilan proses belajar mengajar di sekolah karena media pembelajaran dapat 
membantu guru dalam proses penyampaian informasinya keada siswa dan begitupun sebaliknya dari siswa kepada guru.

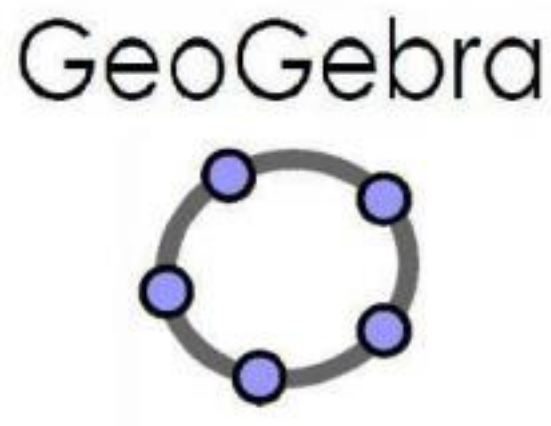

Gambar 1. Simbol GeoGebra

Program GeoGebra merupakan program pelengkap berbagai program yang ada pada komputer untuk membantu pembelajaran aljabar yang memang sudah ada, contohnya seperti Maple, Derive, MuPad, ataupun program komputer untuk membantu pembelajaran geometri, contohnya seperti Geometry's Sketchpad atau CABRI. Program-program yang terdapat dalam komputer tersebut dimaksudkan secara lebih spesifik adalah untuk mengajarkan serta memberi pemahaman terhadap aljabar atau pembelajaran geometri secara terpisah.

Salah satu program GeoGebra untuk pembelajaran konsep geometri yaitu adanya fasilitas berbentuk animasi dan gerakan-gerakan manipulasi (dragging) yang memberikan pengalaman secara visual dan lebih jelas pada siswa. Fasilitas ini dapat sangat membantu guru dalam menyampaikan konsep geometri. Guru dapat menggambar titik, polygon, vector, garis, ruas garis, lingkaran, kerucut, irisan, dan kurva 2 dimensi. Guru juga dapat membuat berbagai gambar bangun ruang pada program GeoGebra tersebut serta membuat animasinya. Animasi dan gerakan-gerakannya akan sangat menarik perhatian siswa sehingga diharapkan siswa akan mudah mengingat dan memahami penyampaian konsepnya.

Selain membuat animasi dari berbagai bentuk bangun ruang, GeoGebra juga dapat mencari volume bangun ruang dengan sangat mudah melalui fasilitas yang dimilikinya. Jika sebelumnya mencari volume bangun ruang harus menghitung dulu secara manual volumenya, dalam program Geogebra ini mencari volume bangun ruang tidak perlu lagi bersusah-susah menghitung, mengotret untuk mendapatkan hasilnya. Dengan program GeoGebra setiap bangun ruang yang dibuat akan secara otomatis terukur dengan volumenya. Tentu program GeoGebra ini akan sangat memudahkan guru untuk menjelaskan konsep mencari volume bangun ruang tersebut dan begitupun dengan siswa yang akan memudahkan mereka dalam memahami konsep tersebut.

Berdasarkan pemaparan di atas perlu dirancang berbagai macam pemanfaatan suatu media dalam materi geometri yang bersifat abstrak. Berdasarkan latar belakang dan identifikasi masalah maka 
dapat dirumuskan rumusan masalah sebagai berikut: Bagaimanakah penggunaan program Geogebra dalam meningkatkan minat belajar siswa.

\section{METODE}

Metode penelitian yaitu seluruh siswa SD Pangkalan Kota Bandung dengan sample yang digunakan yaitu 29 siswa kelas V (Lima) SD Pangkalan. Perangkat tes yang digunakan dalam mengumpulkan data minat belajar pada penelitian ini adalah skala sikap dengan 20 pernyataan yang terdiri dari pernyataan positif dan negatif. Berikut ini penyataan dari skala sikap :

Tabel 1.

Pernyataan Positif dan Negatif Skala Sikap Minat Belajar

\begin{tabular}{|c|c|c|c|c|c|}
\hline \multirow{2}{*}{ No } & \multirow{2}{*}{ Pertanyaan } & \multicolumn{4}{|c|}{ Respon } \\
\hline & & $\mathbf{S}$ & SS & TS & STS \\
\hline & Indikator: Perasaan senang & & & & \\
\hline 1 & Saya menyukai pelajaran matematika $(+)$ & & & & \\
\hline 2 & $\begin{array}{l}\text { Materi pelajaran matematika bagi saya sangat sulit di } \\
\text { pahami(-) }\end{array}$ & & & & \\
\hline 3 & $\begin{array}{l}\text { Saya sangat memperhatikan selama proses pembelajaran } \\
\text { berlangsung }(+)\end{array}$ & & & & \\
\hline 4 & Saya tidak bersemangat setiap kali diberi tugas rumah $(\mathrm{PR})(-)$ & & & & \\
\hline 5 & $\begin{array}{l}\text { Saya senang belajar volume bangun ruang menggunakan } \\
\text { program GeoGebra ini }(+)\end{array}$ & & & & \\
\hline \multirow[t]{2}{*}{6} & Saya mau belajar matematika jika akan ulangan(-) & & & & \\
\hline & Indikator: Ketertarikan siswa & & & & \\
\hline 7 & $\begin{array}{l}\text { Materi volume bangun ruang menggunakan program } \\
\text { Geogebra mudah dipahami }(+)\end{array}$ & & & & \\
\hline 8 & Menurut saya, saya lebih suka belajar seperti biasa(-) & & & & \\
\hline 9 & $\begin{array}{l}\text { Pada awal pembelajaran saya melihat ada sesuatu yang } \\
\text { menarik bagi saya }(+)\end{array}$ & & & & \\
\hline \multirow[t]{2}{*}{10} & $\begin{array}{l}\text { Saya malu untuk bertanya tentang apa yang saya tidak } \\
\text { pahami(-) }\end{array}$ & & & & \\
\hline & Indikator: Keterlibatan siswa & & & & \\
\hline 11 & Saya aktif selama proses pembelajaran matematika(+) & & & & \\
\hline 12 & $\begin{array}{l}\text { Saya kebingungan ketika belajar menggunakan metode } \\
\text { pembelajaran program geogebra ini(-) }\end{array}$ & & & & \\
\hline 13 & Saya bersemangat mengerjakan soal yang diberikan $(+)$ & & & & \\
\hline \multirow[t]{2}{*}{14} & $\begin{array}{l}\text { Saya tidak menjawab pertanyaan guru karna takut jawaban } \\
\text { saya salah(-) }\end{array}$ & & & & \\
\hline & Indikator: Rajin dalam belajar & & & & \\
\hline 15 & $\begin{array}{l}\text { Saya mencoba menyelesaikan soal matematika tanpa disuruh } \\
\text { guru(+) }\end{array}$ & & & & \\
\hline \multirow[t]{2}{*}{16} & Saya enggan mengerjakan soal yang rumit (-) & & & & \\
\hline & Indikator: Tekun dalam belajar dan disiplin & & & & \\
\hline 17 & $\begin{array}{l}\text { Mendapatkan nilai matematika adalah sangat penting bagi } \\
\text { saya }(+)\end{array}$ & & & & \\
\hline 18 & $\begin{array}{l}\text { Materi yang disampaikan kurang menarik untuk di } \\
\text { pelajari(-) }\end{array}$ & & & & \\
\hline 19 & $\begin{array}{l}\text { Ketika belajar dengan menggunakan aplikasi program } \\
\text { GeoGebra, } \\
\text { suasana kelas menjadi menyenangkan(+) }\end{array}$ & & & & \\
\hline 20 & Waktu belajar matematika terlalu lama(-) & & & & \\
\hline
\end{tabular}


Teknik pengolahan data pada penelitian ini yaitu teknik dengan menggunakan Microsoft excel. Data pada skala sikap yang tadinya memiliki nilai ordinal diubah menjadi bentuk nilai interval dengan menggunakan bantuan Method of Succesive Interval (MSI) oleh Microsoft excel. Teknik ini merupakan langkah untuk mengolah skala sikap yaitu dengan seperangkat pernyataan dengan jawaban yang telah disediakan dan dipilih oleh responden. Penskoran yang digunakan peneliti menggunakan skala likert yang telah dimodifikasi yaitu: setuju (S), sangat setuju (SS), tidak setuju (TS), dan sangat tidak setuju (STS). Adapun point dari setiap skala adalah sebagai berikut:

\section{Tabel 2.}

Point Skala Sikap Minat Belajar

\begin{tabular}{lcc}
\hline \multicolumn{1}{c}{ Skala } & \multicolumn{2}{c}{ Point } \\
\cline { 2 - 3 } & Positif & Negatif \\
\hline Setuju (S) & 3 & 2 \\
\hline Sangat Setuju (SS) & 4 & 1 \\
\hline Tidak Setuju (TS) & 3 & 2 \\
\hline Sangat Tidak Setuju (STS) & 1 & 4 \\
\hline
\end{tabular}

Skala sikap minat belajar ini digunakan untuk mencari tanggapan dari para responden terhadap minat belajar siswa SD terhadap program GeoGebra pada materi volume bangun ruang. Data yang didapat nantinya akan dijadikan hasil dari penelitian sehingga peneliti dapat menarik kesimpulan dari hasil peneliatian ini. Kemudian dari hasil penelitian ini diklasifikasikan berdasarkan kriteria presentase skala menurut Riduwan (2007):

Table 3

Kriteria Spesifikasi Skala Sikap

\begin{tabular}{|l|l|}
\hline Kriteria (\%) & Klasifikasi \\
\hline $0 \leq \mathrm{NA} \leq 20$ & Sangat Lemah \\
\hline $20 \leq \mathrm{NA} \leq 40$ & Lemah \\
\hline $40 \leq \mathrm{NA} \leq 60$ & Cukup \\
\hline $60 \leq \mathrm{NA} \leq 80$ & Kuat \\
\hline $80 \leq \mathrm{NA} \leq 100$ & Sangat Kuat \\
\hline
\end{tabular}

\section{HASIL}

Hasil dari penelitian ini adalah pengumpulan dari data dan skala sikap minat belajar tanggapan dari responden siswa setelah dilakukan pemberian materi volume pada bangun ruang menggunakan program GeoGebra. Adapun kegiatan-kegiatan yang dilakukan pada saat pemberian pembelajaran adalah sebagai berikut: 


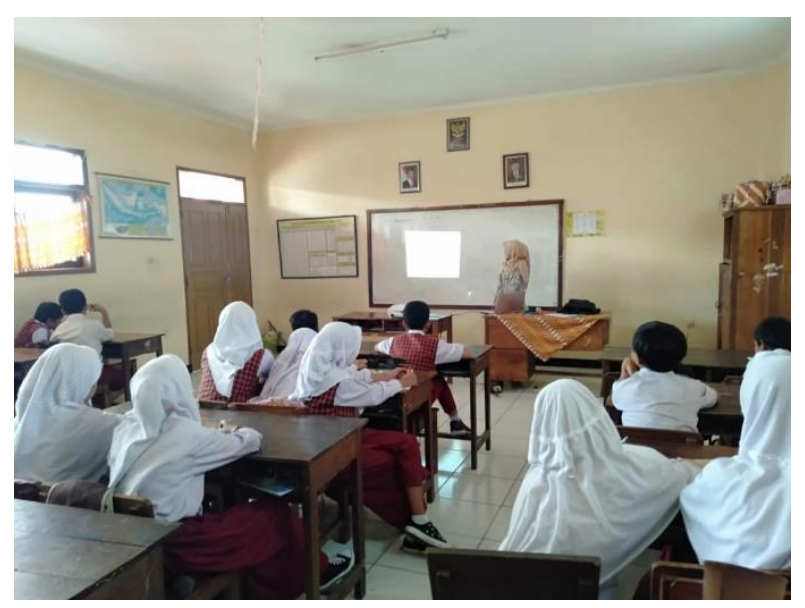

Gambar 1. Siswa sedang diberi materi volume bangun ruang dengan program GeoGebra

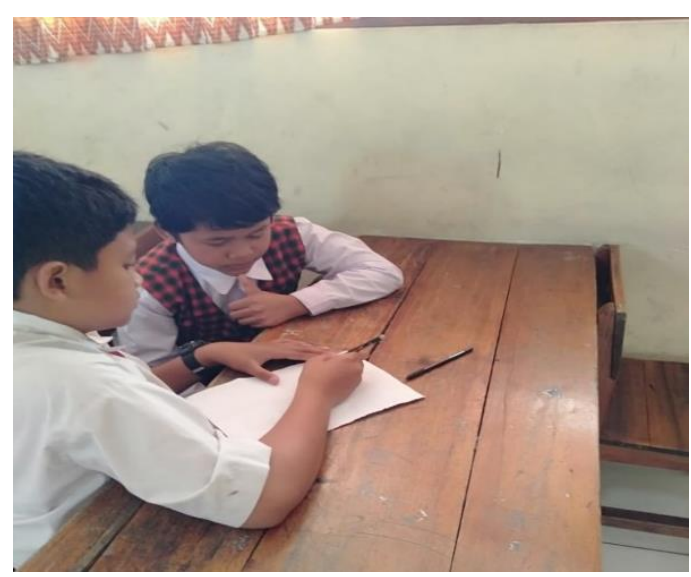

Gambar 2. Siswa sedang mencoba mencari volume bangun ruang dengan menghitung secara manual

Setelah memberikan materi volume pada bangun ruang menggunakan program GeoGebra di SD Pangkalan dengan banyak siswa 29 orang sebagai responden. Maka selanjutnya peneliti melakukan analisis skala minat belajar siswa yang terdiri dari 20 pertanyaan yang meliputi pertanyaan positive dan pertanyaan negative. Selanjutnya hasil data dari penelitian skala minat belajar siswa dapat dilihat pada table dibawah ini:

\section{Tabel 4.}

Presentase Skala Sikap Minat Belajar Siswa

\begin{tabular}{|c|c|c|c|c|c|c|}
\hline \multirow[b]{2}{*}{ No. } & \multirow[b]{2}{*}{ Indikator } & \multirow{2}{*}{$\begin{array}{l}\text { Banyak } \\
\text { Pernyataan }\end{array}$} & \multicolumn{4}{|l|}{ Total } \\
\hline & & & Skor & Mean & $\%$ & Kategori \\
\hline 1. & Perasaan senang & 5 & 363,89 & 12,548 & & KUAT \\
\hline 2. & Ketertarikan siswa & 5 & 394,33 & 13,597 & 66,69 & KUAT \\
\hline 3. & Keterlibatan siswa & 4 & 322,38 & 11,11 & 64,6 & KUAT \\
\hline 4. & Rajin dalam belajar & 3 & 225,81 & 7,78 & 60,29 & CUKUP \\
\hline 5. & $\begin{array}{l}\text { Tekun dalam belajar } \\
\text { dan disiplin }\end{array}$ & 3 & 237,56 & 8,19 & 63,77 & CUKUP \\
\hline Tota & & 20 & 1543,97 & 53,225 & 63,27 & KUAT \\
\hline
\end{tabular}


Dari tabel 4 dapat kita lihat bahwa rata-rata perolehan hasil presentase tiap indicator dari presentase adalah masuk kedalam kategori.

Berikut adalah data deskriptif statistic visual minat belajar siswa:

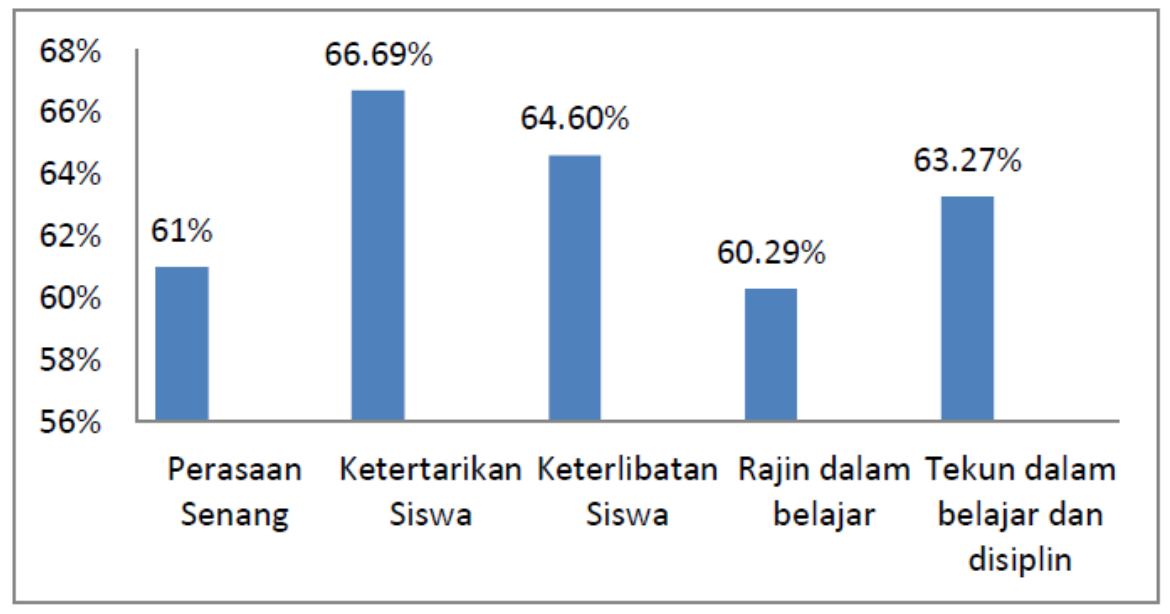

Gambar 3. Gambar Presentase Indikator Pada Minat Belajar Siswa

Jika dilihat dari gambar 3 diagram presentase pada indicator minat belajar siswa untuk indicator perasaan senang memperoleh presentase $61 \%$. Terlihat dari indicator ketertarikan siswa, indicator ini mendapatkan presentase yang paling tinggi dari indicator yang lainnya dengan perolehan presentase 66,69\%. Selain dari pada itu pada indicator keterlibatan siswa, presentase yang diperoleh sebesar $64,60 \%$. Hanya terdapat satu indicator yang memperoleh kategori cukup yaitu indicator rajin dalam belajar. Dengan perolehan hasil presentase $63,27 \%$ dan yang terakhir untuk indicator tekun dalam belajar dan disiplin mendapatkan hasil presentase 60,29\%.

Berdasarkan data diatas terlihat bahwa rata-rata respon siswa SD pada pembelajaran volume bangun ruang menggunakan program GeoGebra mendapatkan respon yang positif. Factor-faktor yang mempengaruhi siswa dalam mengikuti pembelajaran dengan hasil yang positif, dikarenakan proses dari pembelajaran dengan penggunaan program GeoGebra dirasa lebih banyak diminati siswa. Hal itu dapat terlihat saat siswa memperhatikan demontrasi guru di kelas. Dan respon siswa setelahnya jauh lebih berminat kepada program GeoGebra tersebut. Respon tersebut mendapat hasil rata-rata minat belajar siswa yang paling kuat dan itu akan mempengaruhi hasil belajar siswa.

Pencapaian seorang siswa dalam suatu pembelajaran adalah bergantung kepada minat siswa .

Baik dan berhasilnya dikarenakan minat belajar yang kuat dan begitupun dengan pemahaman pembelajaran siswa yang baik pula. Oleh karena itu, kita dapat simpulkan bahwa minat belajar siswa dengan menggunakan GeoGebra dapat memberikan dampak positif pada minat belajar siswa dan berpengaruh pula pada hasil belajar siswa.

\section{KESIMPULAN}

Dari hasil analisis data berdasarkan yang sudah dipaparkan diatas disimpulkan bahwa pembelajaran pada volume bangun ruang pada siswa kelas V (Lima) SD Pangkalan yang 
pembelajarannya menggunakan GeoGebra pada pembelajaran volume bangun ruang memperoleh respon positif dimana rata-rata siswa mempunyaiindikator minat belajar siswa yang kuat. Pengalaman baru yang diperoleh siswa dengan pembelajaran berbasis ICT dengan penggunaan program GeoGebra menjadikan siswa mempunyai rasa ingin tahu yang cukup tinggi dan itu menimbulkan perasaan senang pada diri siswa. Perasaan senang tersebut juga mendorong siswa aktif dikelas dan terlibat dalam pembelajaran bukan sekedar mendengarkan penjelasan tetapi juga ikut mencoba merasakan hal baru yang mereka peroleh. Hal tersebut juga yang menjadi factor siswa memiliki minat belajar yang baik.

Untuk peneliti selanjutnya, diharapkan dapat mengembangkan hasil penelitian ini dalam ruang lingkup yang lebih luas. Seperti menurut Slameto dalam (Hamidah \& Setiawan, 2015), menyatakan bahwa minat yaitu sesuatu yang menambahkan rasa lebih menyukai dan lebih tertarik terhadap sesuatu yang mampu meningkatkan kualitas pembelajaran. Maka dari itu diharapkan peneliti selanjutnya pun mampu menambahkan rasa suka dan ketertarikan minat belajar siswa yang khususnya untuk pembelajaran matematika dengan menggunakan program GeoGebra.

\section{DAFTAR PUSTAKA}

Hamidah, N., \& Setiawan, W. (2015). Analisis minat belajar siswa sma kelas xi pada materi matriks. 01(02), 457-463.

Jamal, F. (2014). Analisis Kesulitan Belajar Siswa Dalam Mata Pelajaran Matematika Pada Materi Peluang Kelas XI IPA SMA Muhammadiyah Meulaboh Johan Pahlawan. Jurnal MAJU (Jurnal Pendidikan Matematika), 1(1), 18-36. $\quad$ Retrieved from http://www.ejournal.stkipbbm.ac.id/index.php/mtk/article/view/232

Kartika, H. (2014). Pembelajaran Matematika Berbantuan Software Matlab sebagai Upaya Meningkatkan Kemampuan Komunikasi Matematis dan Minat Belajar Siswa SMA. Jurnal Pendidikan Unsika, 2(1), 24-35. https://doi.org/10.22342/jpm.10.2.3637.93-108

Masykur, R., Nofrizal, N., \& Syazali, M. (2017). Pengembangan Media Pembelajaran Matematika dengan Macromedia Flash. Al-Jabar: Jurnal Pendidikan Matematika, 8(2), 177. https://doi.org/10.24042/ajpm.v8i2.2014

Rahmawati, N. S., Bungsu, T. K., Islamiah, I. D., \& Setiawan, W. (2015). Analisis Minat Belajar Siswa Ma Al-Mubarok Melalui. 01(03), 386-395.

Ramdhani, S. (2017). Pengembangan Media Pembelajaran Moodle. Jurnal Penelitian Pembelajaran Fisika, 7(2), 95-110. https://doi.org/10.26877/jp2f.v7i2.1311

Sirait, E. D. (2016). Pengaruh Minat Belajar Terhadap Prestasi Belajar Matematika. Formatif: Jurnal Ilmiah Pendidikan MIPA, 6(1), 35-43. https://doi.org/10.30998/formatif.v6i1.750

Leshin, Pollock \& Reigeluth. (1992). Instructional Design Strategies and Tactics. Englewood Cliffs, NJ: Educational Technology Publication.

Slameto. 2010. Belajar \& Faktor-Faktor Yang Mempengaruhinya. Jakarta: PT Rineka Cipta. 